\title{
Transport Requirements for Energy and Resources
}

\author{
L. Špička*, J. Jedlička, R. Cholava \\ Transport Research Centre, Brno, Czech Republic \\ *Corresponding author: libor.spicka@cdv.cz
}

DOI: $10.2478 / \mathrm{v} 10158-011-0007-7$

\begin{abstract}
This article provides a comprehensive look at the energy and resources required for transport and also at the benefits and disadvantages of replacing conventional energy resources in transport. Besides the issue of replacing fossil fuels, it also describes various trends in alternative drives, which are compared with conventional drives, in terms of energy efficiency and environmental impact.
\end{abstract}

KEY WORDS: transport, energy, non-renewable resources.

\section{INTRODUCTION}

The growth of energy needs in transport directly depends on the environment impact, which is further related to the health of population, economic growth of countries, social conditions, etc. The effects of energy consumption on the environment can be divided into two areas. The first area is a steady growth in the consumption of non-renewable fossil energy resources, which is in opposition to the principles of sustainable development. The other area is a growing impact on the environment, particularly by air pollution, due to the continuous increase in the amount of the consumed fuel. Emissions of carbon dioxides $\left(\mathrm{CO}_{2}\right)$, one of the most important greenhouse gases produced by transport, are directly based on fuel consumption, i.e. energy, in comparison with other emissions.

The primary used fuel in transport, and therefore the source of energy in transportation, is petrol and diesel fuel, which is produced from crude oil. Nowadays, the consumption in the transportation sector reaches approximately $40 \%$ of the global oil consumption. This proportion of the transport sector in oil consumption is estimated to grow steadily, in theory even up to $90 \%$ in 2050 (Birky et al., 2001). Whereas oil consumption in energy, residential, and commercial sectors will decline, the trend in transportation will be quite opposite. A huge growth in oil consumption in the transport sector will increase significantly due to the considerable growth of the global number of vehicles which is expected particularly in the developing countries. For example, 8.5 vehicles per 1000 inhabitants were registered in China in 1998, which corresponds with statistics of vehicle ownership in the USA in 1912. 112.63 vehicles per 1000 inhabitants were registered in 2006, respectively 39.43 passenger cars. Another reason for growing energy consumption in transport is the higher mileage of vehicles. Whereas in 2000 the share of transport in oil consumption was 30 million barrels of oil a day of the global daily consumption of 75 million barrels of oil ( 1 barrel $=159$ litres), it is assumed that in 2050the global oil consumption 
will rise to 186 million barrels a day, out of which 170 million will be consumed by transport (Birky et al., 2001). In contrast to stable gradual increase in energy consumption in developed countries, a rapid increase in energy consumption by transport in developing countries is expected, which will certainly have a global impact on the environment of the whole planet.

\section{ENERGY CONSUMPTION BY TRANSPORT}

The increase in the number of vehicles and in the mileage of vehicles goes hand in hand with the growth of energy consumption, which from 1993 to 2005 increased by almost $75 \%$ in the transport sector. The most significant growth in energy consumption occurred in individual car transport, road freight transport, and aviation. On the other hand, consumed energy significantly decreased in water transport and rail transport, which was caused by the consumer preference for road freight transport. The energy consumption is directly related to the consumption of fuel, whose sale almost doubled in the Czech Republic from 1993 to 2005. The most considerable growth was observed in diesel fuel, which is connected both to a significant increase in freight transport in the Czech Republic and the growing popularity of diesel fuel cars in individual car transport.

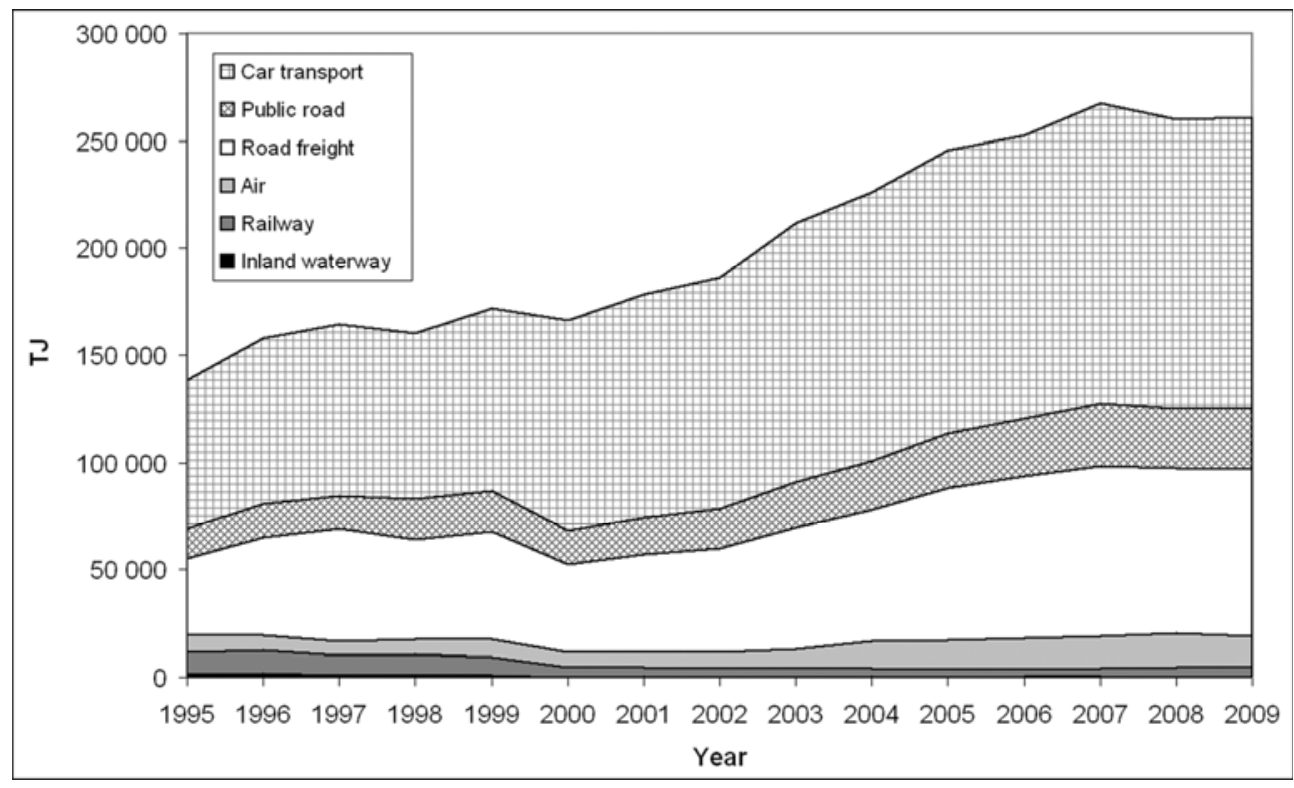

Figure 1: Energy consumption by transport in the Czech Republic.

\section{CURRENT ALTERNATIVES TO CONVENTIONAL ENERGY RESOURCES}

Virtually nobody can imagine nowadays that within a very short period of time the automobile petrol and diesel fuel may be replaced by new fuel or by an utterly new drive of the vehicle. On the other hand, hardly anybody is aware of the non-renewability of these fuels as well as the real threat of the future shortage of this energy resource, which should be used much more efficiently. Oil is raw fossil material found in underground layers and extracted in so-called oilfields. The majority of the largest oilfields, called "super giants", are found in the Far East. The world's oil reserve estimates are regularly revised and provide information about the development in the world of oilfields. The estimates of world's oil reserves depend on a lot of limited information, such as the depth of extractable oil, rock formation, and many others. The oil reserves should not 
only be associated with the development of oil production; it is just one of the factors on whose basis the development of global oil production is estimated. Other factors are, for example, the history of a given oilfield production, local geographical conditions, available technologies, oil price on the world market, etc.

In connection with the exhaustibility of world's oil reserves, we speak about "the world production oil peak". After discovering an oilfield, oil production at that site grows, until the production peak has been reached. After reaching the peak, the remaining oil reserves are extracted with declining production characteristics. In some cases the oil production decreases very slowly, but reaching the peak production is no longer possible. The lifetime of an oilfield is counted in decades and the production peak is usually reached after about a decade after the discovery of the oilfield. When considering all world's oil reserves, then we refer to the world's oil peak, i.e. reaching the maximum world's oil production, not to the exhausting of oil reserves. The world's oil peak has already been a subject of discussion for a long time since the beginning of the modern oil era, dating back to the mid-19th century. Even now, after acquiring new knowledge about oil technology, the estimates of an oil peak are still only a speculation with high degree of uncertainty.

The world experts on oil also differ in their estimates on reaching the world's oil peak. Some of them expect a new oil peak to come in a very short time, others place arguments for the abundant amount of oil for a time period longer than a decade. The arrival of the oil peak by 2010 was predicted by e.g. C. Skrebowski, editor of Petroleum Journal, as well as the non-government world organization World Energy Council. De Almeida \& Silva (2009) also expect to reach the global oil peak around the end of the first decade of the $21^{\text {st }}$ century. The Energy Information Administration, CERA (energy consultants of the USA), as well as the company Shell, predict the arrival of a new oil peak after 2020. The American company EIA (Energy Information Administration) produced an extensive study of scenarios on the exhaustion of world's oil reserves. On the basis of the assumption of a $2 \%$ yearly increase in the global demand for oil, the production oil peak is to be expected in 2037 (Wood et al., 2004) with the demand for oil reaching 53.2 billion barrels a year.

Table 1: The conventional fuel savings when using the driving systems of the vehicles.

\begin{tabular}{|c|c|c|c|c|c|}
\hline Fuel & $\begin{array}{r}\text { Efficiency } \\
\text { potential }\end{array}$ & $\begin{array}{l}\text { Exhaust } \\
\text { emissions }\end{array}$ & $\begin{array}{c}\text { Date of the } \\
\text { market launch }\end{array}$ & Cost increase & Other \\
\hline $\begin{array}{l}\text { More } \\
\text { efficient } \\
\text { conventional }\end{array}$ & Mild & $\begin{array}{l}\text { Gradually } \\
\text { decreasing }\end{array}$ & $\begin{array}{l}\text { Present or } \\
\text { short-term } \\
(0-5 \text { years }) \\
\end{array}$ & $\begin{array}{l}\text { Minimum } \\
(5 \%)\end{array}$ & $\begin{array}{l}\text { Favourable } \\
\text { for customers, } \\
\text { depends on oil }\end{array}$ \\
\hline Hybrid & Important & Nearly zero & \begin{tabular}{|l|} 
Short-term \\
$(2-7$ years $)$
\end{tabular} & $\begin{array}{l}\text { Significant } \\
(10 \%- \\
20 \%)\end{array}$ & $\begin{array}{l}\text { Growing } \\
\text { interest, } \\
\text { accepted } \\
\text { by producers }\end{array}$ \\
\hline Fuel cells & Very high & $\begin{array}{l}\text { Very low, } \\
\text { nearly zero }\end{array}$ & $\begin{array}{l}\text { Middle-term } \\
(5-12 \text { years })\end{array}$ & $\begin{array}{l}\text { Very high } \\
(>20 \%)\end{array}$ & $\begin{array}{l}\text { Potential oil } \\
\text { independence }\end{array}$ \\
\hline Electric & Very high & Zero & \begin{tabular}{|l} 
Short-term \\
$(2-7$ years $)$
\end{tabular} & $\begin{array}{l}\text { Very high } \\
(>20 \%)\end{array}$ & $\begin{array}{l}\text { Capacity } \\
\text { of accumulators }\end{array}$ \\
\hline
\end{tabular}

With both the continually growing demand for oil with a yearly increase of $2 \%$ and reaching the production oil peak, the effect of jaws opening will appear when the demand for oil grows and the world oil production decreases. This phenomenon is called by experts the "oil gap" and it deals with the energy difference between the demand for oil and limited oil supplies. The oil gap, however, cannot be considered to be an energy crisis, as it has been 
indicated in some cases, due to several times larger resources of fossil fuels used in the energy industry (coal, natural gas, etc.) in comparison with oil reserves. The most serious effect of the oil shortage threatens the transportation sector. Therefore, it is necessary now to address the issue of how to fill the oil gap.

One of the ways to achieve energy supplies after reaching the world oil peak is to extract energy from unconventional fossil resources, whose world reserves are enormous it is estimated that the energy reserves of unconventional fossil resources are a hundred times bigger than the total energy resources of the conventional fossil resources. The unconventional oil resources are the oil-bearing sands, shale gas, and heavy oil, whose processing is economically and technologically too demanding so far. The other option is the production of synthetic motor fuels from natural gas, GTL technology (Gas to Liquids) with the use of the technology of obtaining natural gas from methane hydrates. Hydrates and the technology for their production are in the early stages of research.

Another way to assure the energy in the transport sector is the development of new, andan improvement of the existing, driving systems of vehicles (hybrid and electric drive, fuel cells, etc.) while developing new alternative fuels (bio-fuels, natural gas, hydrogen, etc.).

Table 2: Comparing the potential of transport fuels.

\begin{tabular}{|c|c|c|c|c|}
\hline Fuel & Renewability & $\begin{array}{l}\text { Status of the } \\
\text { technology }\end{array}$ & $\begin{array}{c}\text { Needs of the } \\
\text { infrastructure / } \\
\text { costs }\end{array}$ & Other obstacles \\
\hline Oil & Final & Developed & No & $\begin{array}{l}\text { Continuing huge } \\
\text { carbon emissions }\end{array}$ \\
\hline $\begin{array}{l}\text { Unconventional } \\
\text { oil }\end{array}$ & $\begin{array}{l}\text { Final, but huge } \\
\text { reserves }\end{array}$ & $\begin{array}{l}\text { Short-term even } \\
\text { mid-term } \\
\text { availability } \\
(5-10 \text { years })\end{array}$ & Minimal & $\begin{array}{l}\text { High extraction } \\
\text { costs }\end{array}$ \\
\hline $\begin{array}{l}\text { Methane } \\
\text { hydrates }\end{array}$ & $\begin{array}{l}\text { Final, but huge } \\
\text { reserves }\end{array}$ & $\begin{array}{l}\text { Long-term } \\
\text { availability } \\
(7-12 \text { years })\end{array}$ & Mild & $\begin{array}{l}\text { Unknown } \\
\text { technology }\end{array}$ \\
\hline Bio-ethanol & $\begin{array}{l}\text { Renewable } \\
\text { resource, limitation } \\
\text { by the area }\end{array}$ & $\begin{array}{l}\text { Short-term } \\
\text { availability } \\
(0-15 \text { years })\end{array}$ & Minimal & $\begin{array}{l}\text { High production } \\
\text { costs }\end{array}$ \\
\hline Biodiesel & $\begin{array}{l}\text { Renewable } \\
\text { resource, limitation } \\
\text { by the area }\end{array}$ & $\begin{array}{l}\text { Short-term } \\
\text { availability } \\
(0-5 \text { years })\end{array}$ & Minimal & $\begin{array}{l}\text { High production } \\
\text { costs }\end{array}$ \\
\hline Methanol & Final & Developed & Mild & Toxicity \\
\hline Natural gas & Final & Developed & Significant & $\begin{array}{l}\text { Storage, growing } \\
\text { price }\end{array}$ \\
\hline Biogas & $\begin{array}{l}\text { Renewable } \\
\text { resource, limitation } \\
\text { by the area }\end{array}$ & $\begin{array}{l}\text { Short-term } \\
\text { availability } \\
(0-15 \text { years })\end{array}$ & Significant & $\begin{array}{l}\text { Distribution, } \\
\text { storage }\end{array}$ \\
\hline Electricity & $\begin{array}{l}\text { Depends on primary } \\
\text { source }\end{array}$ & Developed & Significant & Storage \\
\hline Hydrogen & $\begin{array}{l}\text { Potentially huge, } \\
\text { depends on the } \\
\text { resource }\end{array}$ & $\begin{array}{l}\text { Short-term even } \\
\text { long-term } \\
\text { availability } \\
(5-12 \text { years })\end{array}$ & Very high & Storage security \\
\hline
\end{tabular}




\subsection{Bio-fuels}

At present we are almost unable to find a daily or specialized press which does not mention the replacement of fossil fuels with bio-fuels, which are, in the case of motor fuels, produced from biomass. These are mainly biodiesel, bio-ethanol, and biogas. The replacement of the part of fossil fuels by renewable resources is also one of the strategic goals of the European Community whose partial goals are to reduce the dependency on oil imports, reduction of the transport impact on the environment, new jobs in agricultural, etc. The requirements for the use of bio-fuels are determined in the White Paper, in "European Strategy for Sustainable Development" (European Commission, 2001) and particularly in the European Directive 2009/28/EC (European Commission, 2009), which is implemented in the Czech legislation with the amendment of the Act on air protection, in which the obligatory mixtures of bio-components in petrol and diesel are specified. Since June 2010 the share of bio-components has reached $4.1 \%$ for petrol and $6.0 \%$ for diesel.

The technical term biodiesel means $100 \%$ pure fatty acid methyl esters (FAME), which are made by reesterification of plant or animal oils and methanol. The oilseed rape, from which methyl esters of the fatty acids of seed oil are produced, is the most important raw material for the production of biodiesel in the Czech Republic, and foreign production of FAME comes from soya, palm oil, and other oil products. The fatty acid methyl esters are fuel which is approved by the announcement of the Ministry of Industry and Trade, which specifies the requirements for fuels for road traffic; and the method of monitoring their quality and their parameters are defined by the standard ČSN EN 14214 (656507) Automotive fuels - Fatty acid methyl esters (FAME) for diesel engines - Requirements and test methods. The offer of car fuels include $100 \%$ pure methylester fatty acids as well as mixed motor fuel composed of diesel and biodiesel additives, usually of $20 \%$ (mainly abroad) and 30\%.

By operating vehicles using biodiesel the impact on the environment is reduced, in comparison with the vehicles using diesel. The results of studies which measured the emissions during biodiesel combustion have demonstrated the influence of the quantity of added biodiesel into conventional fuel, in relation to the quantity of the emitted air pollutants. The declining dependency of the quantity of the emitted particulate matter (PM), carbon oxide $(\mathrm{CO})$, hydrocarbons $(\mathrm{HC})$ on the growing content of the mixed biodiesel is demonstrated. On the contrary, due to the physical-chemical properties of the fuel, the emissions of nitrogen oxide $\left(\mathrm{NO}_{\mathrm{x}}\right)$ proportionally grow with the increasing quantity of the mixed biodiesel (U.S. Environmental Protection Agency, 2002). In the past, the vehicles running on biodiesel needed adjustments of the fuel systems considering their aggressive effects on the rubber parts. Nowadays, several car manufacturers have already approved biodiesel or mixed motor fuel for operation in mass-produced vehicles.

In the Czech Republic bio-ethanol is an alcohol fuel made from sugar-beet or cereals, from maize; sugar cane, and potatoes abroad. We distinguish two types in this fuel, fuel for petrol engines, and fuel for diesel engines. For petrol engines mixed motor fuels are used, the fuel with a low content of bio-ethanol (it is currently possible to add $5 \%$ of alcohol to petrol), and fuel with a high content of bio-ethanol (so-called E85) composed of a mixture of $85 \%$ waterless bio-ethanol and $15 \%$ petrol. However, fuel E85 cannot be used in the mass- produced vehicles running on automobile petrol. Special vehicles called "flexi fuels" were constructed for this fuel, for which, on the basis of the evaluation of the type of fuel mixture, the optimum conditions of combustion are set. These flexi fuel vehicles can be run on an arbitrary mixture of bio-ethanol and automobile petrol, with a content of bio-ethanol ranging from $0 \%$ up to $85 \%$. As an example of European producers of flexi fuel vehicles, the companies Ford, Renault, Saab, Volvo and Škoda could 
be mentioned. The company Saab introduced a flexi fuel vehicle model which could run on $100 \%$ pure bio-ethanol. The "alcohol-fuelled" vehicles are characterized by lower emissions of some pollutants during their operation and then by reduced $\mathrm{CO}_{2}$ emissions, which is a consequence of the renewability of ethanol and thus by the circulation of carbon in the ecosystem. However, the results of foreign studies differ in opinions over the efficiency of production and the use of bio-ethanol in transport and the environmental impact of vehicles running on these fuels (Patzek, 2006).

For diesel engines of trucks the fuel marked E95 is used; it is composed of waterless ethanol and additives. The most important European country in terms of the operation of ethanol buses is Sweden, where SCANIA buses running on bio-ethanol are operated. The ethanol buses are able to meet the current emission limit of EURO V. The disadvantage of these vehicles is their high consumption which is in urban areas nearly $45 \%$ (Capaccioli, 2009) or even 70\% (Matějovský, 2005) higher than the consumption of diesel buses, and expenses for their maintenance are higher by approximately 50\% (Matějovský et al., 2006). The ethanol buses in the Czech Republic are being used in a pilot project, but are expected to be supplied to the Czech market together with the infrastructure development.

Table 3: Effects of emission factors of mixed fuels of used passenger cars.

\begin{tabular}{|l|l|c|c|l|}
\hline \multirow{2}{*}{ Fuel - used passenger car (Euro 3) } & \multicolumn{4}{|c|}{ Emission of the pollutants } \\
\cline { 2 - 5 } & $\begin{array}{c}\text { CO } \\
\left(\mathrm{g} \cdot \mathrm{km}^{-1}\right)\end{array}$ & $\begin{array}{c}\mathbf{N O}_{\mathrm{x}} \\
\left(\mathrm{g} \cdot \mathrm{km}^{-1}\right)\end{array}$ & $\begin{array}{c}\mathbf{H C} \\
\left(\mathrm{g} \cdot \mathrm{km}^{-1}\right)\end{array}$ & $\begin{array}{c}\text { PM } \\
\left(\mathrm{g} \cdot \mathrm{km}^{-1}\right)\end{array}$ \\
\hline Limits EURO 3 - diesel & 0.640 & 0.500 & - & 0.050 \\
\hline Diesel & 0.697 & 0.770 & 0.107 & 0.024 \\
\hline Diesel + 5 \% FAME & 0.587 & 0.784 & 0.121 & 0.025 \\
\hline Diesel + 31 \% FAME & 0.734 & 0.442 & 0.120 & 0.017 \\
\hline Limits EURO 3 - petrol & 2.300 & 0.150 & 0.200 & - \\
\hline Petrol & 0.828 & 0.455 & 0.127 & - \\
\hline E85 & 0.145 & 0.012 & 0.026 & - \\
\hline
\end{tabular}

When mentioning the use of bio-fuels, particularly in terms of the technological and raw materials requirements, it is necessary to take into consideration the negative local effects, as well as global environmental effects, The global negative aspect is the high demand for agricultural raw materials for bio-fuel production, which is also linked to economic subsidies to the growers of these crops. This high demand and support for the cultivation of bio-fuel feedstock are most recently linked to the high demand for agricultural land for cultivating sugar-cane and soya in Brazil, which have an unambiguous influence on the increase in the deforestation of Brazilian rainforests, whose rate is approximately 3 million hectares a year. Another example of the negative impact of growing crops for biofuels is a huge increase in maize prices in the world market, which is reflected in situations in Mexico, where maize products are the traditional food components. A somewhat local, but still inadequately solved, problem of bio-fuel production is the energy analysis of the whole production life cycle, the so-called "well-to-wheel" analysis, which means processing of the energy balance including the production of synthetic fertilizers, agriculture cultivation, harvest and processing of agricultural products, production of bio-fuels, transportation to fuel filling stations, and eventually the combustion of the fuel in the vehicle engine. In contrast to the positive energy balance of the life cycle of bio-fuel production in the majority of published studies, recently, studies were published with the "well-to-wheel" 
analysis with a negative energy balance, which demonstrate that for the production of biofuels a higher amount of energy was needed than the amount gained.

The energy balance of the bio-fuel production depends on the standard and use of the agricultural technology in a given locality, climatic and agricultural conditions and on a number of other factors. Based on the above mentioned reasons, it is clear that it is necessary to perform the life cycle analysis (LCA) of bio-fuels for each country in which the plants are grown for bio-fuel production, and fuels are directly produced. Another issue of the current bio-fuel production is the "humane nature" of these technologies, particularly the production of car fuels from nutrition commodity. Therefore, the most important fuel companies engaged in the production as well as the distribution of the bio-fuels stop the development of these technologies and focus their research potential on the production research of so-called second generation bio-fuels. This is mainly the bioethanol production from lignocelluloses biomass, i.e. the extraction from wooden chips, fastgrowing energy plants, straw, pressed sugar beet, etc.

This technology has already been mastered technically, but the commercial production is still very expensive and the commercial use of the second generation of bio-fuels is expected to occur within 10 to 15 years. The process of bio-ethanol production from lignocelluloses biomass is, compared to the conventional production from cereals or sugarcane, more difficult in the technological process of hydrolysis of the cellulose biomass into monomeric sugar.

\subsection{Compressed natural gas $(\mathrm{CNG})$}

Natural gas is a fossil fuel whose main component is methane (minimum 85\%), and, in contrast to oil, its reserves are estimated to last for up to 150 years. Natural gas as a fuel in transportation could be gradually replaced by renewable biogas in the future, as is currently being done in Sweden, and thus we can speak about CNG in the context of fuel renewability. At the end of 2009, more than 11.3 million vehicles were in operation in the world powered by compressed natural gas, and the number of filling stations was estimated to be approximately 17 000. 1.3 million vehicles and approximately 3490 filling stations are operated in Europe. Italy has the leading position in the use of CNG in Europe with the number of vehicles reaching more than 677800 , followed by Germany with approximately 84850 vehicles. There were approximately 1960 vehicles powered by compressed natural gas registered in the Czech Republic an the end of 2009, out of which there were approximately 270 buses and 20 commercial vehicles. The disadvantage, in comparison to European countries, is the insufficient infrastructure of filling stations, which are gradually being built, and in the early 2010 there were 22 public filling stations operating in the Czech Republic.

On 1 January 2007, the amendment Act 355/2003 Sb., on excise duties came into force in which exempts compressed natural gas from excise duty. The excise duty will be increased in the future in order to reach the value $3335 \mathrm{CZK} \mathrm{t}^{-1}$ in 2020. Support of natural gas in transportation in the Czech Republic is guaranteed by the government resolution no. 563 within the Programme for the support of alternative fuels, and furthermore a voluntary agreement between the state and gas companies (ČPS, 2006) leading to the use of natural gas as an alternative fuel in the transportation.

The gas companies and the state, among other things, committed to:

- Gas companies will build filling stations for $\mathrm{CNG}$ at the place where the local authorities make a decision to transform the vehicle fleet of the urban and suburban transport (or its parts) into the fleet running on natural gas and where it would be 
allowed by the local technical conditions of the gas network. The condition for building a filling station is the minimum number of 4 buses or vehicles with similar natural gas consumption, approximately 100 thousand $\mathrm{m}^{3}$ in the first year. The minimum annual consumption will reach 400 thousand $\mathrm{m}^{3}$ within 4 years from its implementation.

- By 2020, in relation to the targets according to the government resolution no. 563/2005 Sb., on the transport share of natural gas consumption amounting to $10 \%$, gas companies will build a CNG filling station network in the total extent of 100 filling stations.

- As a marketing support of regional and urban public transport, gas companies will provide a subsidy of CZK 200000 for a newly acquired bus running on compressed natural gas, up to a maximum amount of CZK 10 million per year, and they will be offered a bus advertising space at the appropriate extent for the further project presentation of the project.

- The government will support the use of natural gas in transport as one of the priorities of the National programme of economic use of energy and renewable and secondary resources for $2006-2009$.

Although compressed natural gas is currently not a renewable energy resource, its significant benefit in terms of quality for the environment, as well as human health, is the lower production of pollutants during operation in contrast to diesel and petrol vehicles. Although it is possible to convert passenger cars to run on this fuel, the expected trend is to purchase new manufactured $\mathrm{CNG}$ vehicles, rather than mass vehicle conversion, which does not significantly contribute to the quality of the environment.

In the Czech Republic, only a limited range of passenger and commercial vehicles powered by this fuel is currently available (e.g. the makes Fiat, Opel, Mercedes-Benz, Volkswagen and Iveco).

Table 4: Comparison of emission factors of gas vehicles, CNG conversion of used cars and CNG vehicles directly from manufacturer.

\begin{tabular}{|l|l|l|l|}
\hline $\begin{array}{c}\text { Pollutant } \\
\left(\mathrm{g} \cdot \mathrm{kWh}^{-1}\right)\end{array}$ & Petrol & CNG conversion & $\begin{array}{c}\text { CNG from } \\
\text { manufacturer }\end{array}$ \\
\hline $\mathrm{CO}$ & 0.828 & 15.413 & 0.090 \\
\hline $\mathrm{NO}_{\mathrm{x}}$ & 0.455 & 0.052 & 0.081 \\
\hline $\mathrm{HC}$ & 0.127 & 1.735 & 0.058 \\
\hline
\end{tabular}

The Czech Republic is an important producer of CNG buses even in global perspective. There are several manufacturers including SOR Libchavy, and Tedom. The other foreign manufacturers supply CNG buses to the local market - Irisbus, Mercedes-Benz, Solaris, and Volvo. With the use of CNG buses, the emissions of pollutants produced by urban public transport in urban agglomerations can be reduced significantly, especially $\mathrm{NO}_{\mathrm{x}}$ and PM emissions. CNG buses meet the emission limit EURO $\mathrm{V}$ and emission limits of enhanced environmentally friendly vehicle (EEV).

The European Community also introduced a support for the development of petrol engines reaching the designed emission limit EURO VI, which focuses considerably on 
the reduction of exhaust emissions of $\mathrm{NO}_{\mathrm{x}}$ and $\mathrm{PM}$. This was introduced within $\mathrm{R} \& \mathrm{D}$ programme of the $7^{\text {th }}$ Framework Programme.

Table 5: Comparison of emission factors of CNG bus engines.

\begin{tabular}{|l|l|l|l|l|}
\hline $\begin{array}{c}\text { Pollutant } \\
\left(\mathrm{g} \cdot \mathrm{kWh}^{-1}\right)\end{array}$ & $\begin{array}{c}\text { Limits of ETC } \\
\text { test (since 2008) }\end{array}$ & EKOBUS ${ }^{\text {1) }}$ & $\begin{array}{c}\text { ŠKODA LIAZ } \\
\text { 637 NGS }\end{array}$ & IVECO CNG \\
\hline $\mathrm{CO}$ & 4.00 & 0.012 & 0.26 & 2.09 \\
\hline $\mathrm{NMHC}$ & 0.55 & 0 & 0.08 & 0.07 \\
\hline $\mathrm{CH}_{4}$ & 1.10 & 0.25 & 0.09 & 0.20 \\
\hline $\mathrm{NO}_{\mathrm{x}}$ & 2.00 & 2.08 & 0.17 & 0.25 \\
\hline $\mathrm{PM}$ & 0.03 & & & \\
\hline
\end{tabular}

1) according to Ekobus (2009)

2) according to Laurin \& Bartoníček (2003)

3) according to Kalousek (2010)

\subsection{Hybrid drives}

Hybrid drives combining a combustion engine with an electric motor, which works as a generator of electricity for charging the battery (source of electricity for the electric motor) during braking, can be divided into three functional classes: Micro, Mild and Strong.

Micro hybrid drive system is equipped with the system Start/Stop. In urban traffic, vehicles often stop at junctions or in traffic jams. The start/stop system automatically turns off the engine in these cases. When the vehicle can move on, the system quickly restarts the engine after pressing the clutch. With the use of the start/stop system, up to $8 \%$ of the fuel can be saved (Bosch, 2007). With the use of the hybrid system Strong, the consumption of fuel can be reduced by 30 or more percent. The system usually has an electric engine with performance around $50 \mathrm{~kW}$, which guarantees sufficient acceleration during overtaking and furthermore, it allows a trip for shorter distances using only the electric drive. The electric engine can work as a generator as well, and the produced electricity supplies the electrical appliances of the onboard network.

The Japanese automobile factories Toyota/Lexus and Honda are the main global producers of hybrid passenger cars. Whereas Toyota vehicles rely on Strong system of hybrid drives and their vehicles are equipped with $50 \mathrm{~kW}$ electromotors, electric motors of lower performance operating in Mild system are used for Honda vehicles. The majority of European leading producers are also going to offer various types of passenger cars with hybrid drives. As far as cargo vans are concerned, the leading companies are Daimler and Iveco. Regarding heavy goods vehicles, the use of hybrid drives is in the stage of conceptual development and developing projects. For example, Volvo group introduced efficient hybrid drive for heavy vehicles which brings fuel savings up to $35 \%$. Hybrid technology has already been used successfully for several years on a worldwide basis in bus drive systems. European producers have been performing extensive tests of the new technology and solutions have led in some cases (such as Mercedes-Benz, MAN, Solaris, and Volvo) to the stage of mass production. On the basis of long-term tests manufacturers have reported a reduction in fuel consumption by $25-35$ percent. 


\section{ENERGY FOR TRANSPORT IN THE FUTURE}

What kind of fuel will we use in the next 50 years? Will our society come to a stage of oil shortage? Will there be sufficient technologies for energy replacement in transport, caused by oil shortage? These are the issues which experts deal with in almost every science-research institution, engaged in relationship between transport and energy consumption. There is no clear way known to guarantee energy supplies, but the use of combined energy resources, depending on raw materials and the energy possibilities of individual countries, can be expected. Furthermore, in the distant future we can expect the use of biomass for fuel production, which concerns GTL technologies (Gas to liquid) on the basis of synthetic oil production from natural gas via Fischer-Tropsch synthesis. Whereas this technology has been technically mastered since the Second World War, the BTL technology (Biomass to liquid) is in the stage of intensive research and pilot projects. BTL technology is a multi-step process. The first step is the gasification of the biomass. In the next steps the acquired synthesis gas is, converted into an automobile fuel using GTL technologies. Great hopes are currently placed on hydrogen technologies and the electrical drives are up again, having experienced a decline in recent years.

\subsection{Electric drives}

Greater and greater hopes are being placed on electric drives of vehicles, so-called "electromobiles", which were not perspective in the past due to the insufficient capacity of accumulators. Design concepts of electromobiles have undergone certain changes in connection with the technological progress over the recent years. The most significant change is the trend in the installation of electric motors as the vehicle drive as a part of wheel discs, rather than differentials . Another important step is the development of high capacity accumulators. In the past, lead accumulators were gradually replaced with nickel-cadmium and nickel-metal-hydride accumulators, and currently with lithium based accumulators. The development in this field has not finished yet, latest research and development have dealt with the possibilities of using ultra-capacitors, which are special electrolytic condensers with a high capacity up to thousands of Farad and their properties are comparable to electrochemical resources.

The most important technological development in electromobiles was in the USA in the 1990s when the California Air Resources Board institution issued a regulation which required the sale of $2 \%$ of new vehicles meeting the requirement for zero-emission vehicles powered by electricity or alternative fuels (for example hydrogen) in 1998. In 2003 the regulation required the sale of these vehicles to reach $10 \%$ of new vehicles on the market. The extensive programmes of development of electric vehicles in American automobile companies, including foreign manufacturers, such as Ford (Ranger EV), Honda (Honda EV Plus), Toyota (RAV4-EV), Nissan (Altra EV) and others, began with this regulation. These electric vehicles were based on the concept of classic vehicles with a petrol engine. General Motors (GM) took a different course and created an entirely new and unique prototype of an electromobile, EV1, which used the latest technologies in the automotive industry. The availability of the vehicles on the market was aqn interesting decision, because all vehicles were only rented to the customers.

The first EV1 with lead accumulators was launched on the market in 1996. By 2000, 650 examples of EV1 were rented, and between the 2001 and 2002, a number of them were modernized by equipping them with nickel-metal hydride batteries, which enabled an operating range from $120 \mathrm{~km}$ up to $240 \mathrm{~km}$. Some of the examples of technological perfection of EV1vehicles are the aluminium construction of the frame, antilock braking systems, heat pump, keyless control, regenerative braking set, very low 
resistance coefficient $\left(\mathrm{Cd} \sim 0.19, \mathrm{CdA} \sim 0.36 \mathrm{~m}^{2}\right)$, low-rolling resistance tyres, automated tyre pressure loss warning system, etc. In 2002, the GM decided not to continue with the EV1project.

The vehicles were gradually withdrawn from the users and, with some exceptions, gradually scrapped. The main reason for stopping the project was the limited development of high capacity accumulators. Another reason might have been the change of the California Air Resources Board directive in 2003, when the earlier requirement regarding the market share of electric vehicles with zero emissions was mitigated to the distribution of hybrid vehicles or vehicles with fuel cells. At present, the development of electric vehicles is experiencing a renaissance and, apart from small innovative companies like Tesla, Venturi, Think, etc., some large automobile manufacturers are starting to specialize in this type of drive. An advantage of the electromobiles is zero emissions of pollutants and a low environmental impact throughout the whole life cycle, which is specified in Table 6, where the different types of drives are compared.

Table 6: Comparison of different types of drives.

\begin{tabular}{|c|c|c|c|c|}
\hline Technology & Vehicle & $\begin{array}{c}\text { Consumption } \\
(1 / 100 \mathrm{~km})\end{array}$ & \begin{tabular}{|c|}
$\begin{array}{c}\text { Energy efficiency } \\
\text { over the whole life } \\
\text { cycle } \\
\left(\mathrm{MJ} \cdot \mathrm{km}^{-1}\right)\end{array}$ \\
\end{tabular} & $\begin{array}{c}\begin{array}{c}\mathrm{CO}_{2} \text { emissions } \\
\text { over the whole life } \\
\text { cycle }{ }^{3)} \\
\left(\mathrm{g}^{\cdot} \mathrm{km}^{-1}\right)\end{array} \\
\end{array}$ \\
\hline $\begin{array}{l}\text { Petrol engine } \\
\text { (V12) }\end{array}$ & $\begin{array}{l}\text { Ferrari } 599 \\
\text { GTB }\end{array}$ & 17.9 & 6.49 & 431.26 \\
\hline $\begin{array}{l}\text { Petrol engine } \\
\text { (V10) }\end{array}$ & $\begin{array}{l}\text { Lamborghini } \\
\text { Gallardo }\end{array}$ & 14.4 & 5.22 & 349.43 \\
\hline $\begin{array}{l}\text { Petrol engine } \\
\text { (V8) }\end{array}$ & $\begin{array}{l}\text { Ferrari } \\
\text { California }\end{array}$ & 13.1 & 4.75 & 319.04 \\
\hline $\begin{array}{l}\text { Petrol engine } \\
\text { (V6 Turbo) }\end{array}$ & $\begin{array}{l}\text { Porsche } 911 \\
\text { Turbo }\end{array}$ & 11.6 & 4.21 & 283.97 \\
\hline $\begin{array}{l}\text { Petrol engine } \\
\text { (V6) }\end{array}$ & Porsche 911 & 10.3 & 3.74 & 253.57 \\
\hline $\begin{array}{l}\text { Petrol engine } \\
\text { (V4) }\end{array}$ & VW Golf & 6.4 & 2.32 & 162.39 \\
\hline $\begin{array}{l}\text { Petrol engine } \\
\text { (V4 Turbo) }\end{array}$ & VW Golf & 5.2 & 1.89 & 134.34 \\
\hline $\begin{array}{l}\text { Diesel engine } \\
\text { (V4 Turbo) }\end{array}$ & VW Golf & 4.5 & 1.88 & 134.94 \\
\hline $\begin{array}{l}\text { CNG engine } \\
\text { (V4 Turbo) }\end{array}$ & VW Passat & $\begin{array}{l}4.6 \\
\mathrm{~kg} / 100 \mathrm{~km}\end{array}$ & 1.97 & 135.01 \\
\hline $\begin{array}{l}\text { Hybrid } \\
\text { (V4/electromotor) }\end{array}$ & Toyota Auris & 3.8 & 1.38 & 101.60 \\
\hline Fuel cell & Honda FCX & $\begin{array}{l}0,98 \\
\mathrm{~kg} / 100 \mathrm{~km}\end{array}$ & $2.01 / 5.46^{1)}$ & $98.08 / 208.00$ \\
\hline Electric drive & EVC R7 & $\begin{array}{l}12 \\
\mathrm{kWh} / 100 \mathrm{~km}\end{array}$ & 1.24 & 126.09 \\
\hline
\end{tabular}

\footnotetext{
1) hydrogen production via steam reforming of natural gas / electrolysis of water

2) data from manufacturers

3) calculated using Edwards et al. (2007)
} 


\subsection{Hydrogen technologies}

Great hopes are being placed on hydrogen technologies nowadays, because they should replace fossil liquid fuels in transport in the distant future. However, due to the currently slow progress in hydrogen technologies, its high energy intensity of production, and the high production costs of hydrogen production itself as well as the drive technologies, we cannot expect significant use of this fuel in transport by 2030. One of the most significant research workplaces in the field of hydrogen technologies in transport is the company Daimler Chrysler, which, within the project CUTE, constructed thirty-two hydrogen buses, Mercedes Citaro, which have already driven more than million kilometres in ten European cities (HyFLEET:CUTE, 2007).

The vehicles were equipped with fuel cells, which in principle performed the energy conversion of hydrogen and oxygen into electricity, water, and heat via catalytic reactions on the electrodes of the fuel cells. Other hydrogen projects are being dealt with by automobile manufacturers, such as BMW, GM, Honda, Mercedes-Benz, etc. These vehicles are the outcome of long-term research projects and so far they are still not commercially available for the end users. However, an exception exists; Honda launched a limited production of a model FCX Clarity and BMW rented 100 vehicels of the model Hydrogen7.

On the other hand, it is still unclear how the hydrogen will be produced. The most probable three ways of hydrogen production are seen in steam reforming (hydrogen production from natural gas), in water electrolysis (renewable source of hydrogen), or in the thermo-chemical water decomposition with the use of the $4^{\text {th }}$ generation of nuclear reactors (Janík, Doucek, \& Dlouhý, 2010). At a conference "International Hydrogen Day", the company Linde introduced their vision of creating an infrastructure of hydrogen filling stations on German motorways (Linde, 2005). In the first phase, the network would connect German major cities and consist of filling stations located on German motorways within the distance of about $50 \mathrm{~km}$. The extension of the infrastructure to connect the most important European cities is expected by 2020 .

\section{SUMMARY}

As mentioned above, the replacement of non-renewable fossil fuels used in transport will have a positive impact on the environment, under condition that the global policy is in accordance with the principles of sustainability, particularly regarding bio-fuel production. However, the price of alternative fuel is higher than the price of conventional energy resources, which is one of the reasons for the slow development of alternative fuels. Other reasons are the insufficient car fleet and infrastructure for distribution and fuelling. Regarding the current development of alternative fuels and drives, it is possible to realise that future development is not clear at all, and we will surely see distinctive changes, both in technological fuel production and automotive systems.

\section{ACKNOWLEDGEMENTS}

The research described in this article was performed within the research project of the Ministry of Transport of the Czech Republic No. MD 04499457501 "Sustainable Transport - Chance for the Future". 


\section{REFERENCES}

Adamec, V., et al., 2010. Study on transport trends from environmental viewpoints in the Czech Republic 2009. Brno: Centrum dopravního výzkumu, v. v. i., 136 p.

Birky, A., Greene, D., Gross, T., Hamilton, D., Heitner, K. et al., 2001. Future U.S. Highway Energy Use: A Fifty Year Perspective. U.S Department of Energy, 41 p.

Bosch, 2007. Bosch v Česku [online]. (2007, July 10). Retrieved from: http.www.bosch.cz (in Czech)

Capaccioli, S., 2009. Experiences from ethanol buses and fuel station report in La Spezia. BEST Deliverable no: D2.7. Florence: ETA-Renewable Energies, 15 p.

ČPS, 2006. Dobrovolná dohoda mezi státem a plynárenskými společnostmi směřující k rozšíření zemního plynu jako alternativního paliva v dopravě. In Jezdíme na zemní plyn - zkušenosti z provozu [CD-ROM]. Praha, 23. 3. 2006. (in Czech).

de Almeida, P., Silva, P.D., 2009. The peak of oil production-Timings and market recognition. ENERGY POLICY, vol. 37, no. 4, pp. 1267-1276 . ISSN: 0301-4215.

Eberhard, M., Tarpenning, M., 2006. The $21^{\text {st }}$ Century Electric Car [online]. Tesla Motors Inc. (2007, July 7). Retrieved from: http:www.evworld.com/library/Tesla_21centuryEV.pdf

Edwards, R., Larivé, J-F., Mahieu, V., Rouveirolles, P., 2007. Well-to-wheels analysis of future automotive fuels and powertrains in the european context. Ispra (Italy): JRC/IES.

Ekobus, 2009. Ekobus a.s. [online]. (2009, June 9). Retrieved from: http:www.ekobus.cz

European Commission, 2001. White paper - "European transport policy for 2010: time to decide". Luxembourg: Office for Official Publications of the European Communities, 119 pp. ISBN 92-894-0341-1.

European Commission, 2009. Directive 2009/28/EC of the European Parliament and of the Council of 23 April 2009 on the promotion of the use of energy from renewable sources and amending and subsequently repealing Directives 2001/77/EC and 2003/30/EC. Official Journal of the European Union, L 140, pp. 16 - 59.

HyFLEET:CUTE, 2007. HyFLEET:CUTE [online]. (2007, July 10). Retrieved from: http://www.global-hydrogen-bus-platform.com

International Association for Natural Gas Vehicle, 2010. Natural Gas Vehicle Statistics. (2010, May 5). Retrieved from www.iangv.org/tools-resources/statistics.html.

Janík, L., Doucek, A., Dlouhý, P., 2010. Strategická výzkumná agenda vodíkových technologií. Husinec-Řež (Czech Republic): HYTEP - Hydrogen Technology Platform, 49 p. (in Czech)

Jedlička, J., Adamec, V., Cholava, R. et al., 2007. Měření a výpočty emisnich faktori̊ nelimitovaných polutantů při spalování směsných biopaliv v závislosti na jejich složení 
a provoznich režimech (Periodical report of the research project nr. 1F54G/104/520 for year 2006). Brno: Centrum dopravního výzkumu, v.v.i, 32 p. (in Czech)

Kalousek, J., 2010. IVECO a IRISBUS - vozidla na pohon CNG. In Plynofikace dopravy na Přerovsku. Přerov (Czech Republic), 23. 6. 2010. (in Czech)

Laurin, J., Bartoníček, L., 2003. Nízkoemisní autobusový motor na zemní plyn. In $13^{\text {th }}$ International symposium MOTOR SYMPO 2003. Brno, 11. - 12. 6. 2003. Praha: ČVUT,VCJB Praha, pp. 230-237. ISBN 80-02-01561-4. (in Czech)

Linde, 2005. A hydrogen economy is feasible - New study on the cost of a hydrogen infrastructure. Linde Technology : Reports on Science and Technology, pp. 10 - 11. ISSN 1612-2232.

Matějovský, V., 2005. Automobilová paliva. Praha: Grada, 223 pp. ISBN 80-247-0350-5. (in Czech)

Matějovský, V., Třebický, V., Krajiček, I. et al., 2006. Zavádění paliv z obnovitelných zdrojů ve Švédsku. In Proceedings of 7th international conference Motorové palivá 2006. Tatranské Matliare, 19. - 22. 6. 2006. Bratislava: Vedecko-technická spoločnost' při Slovnaft, pp. 625 - 633. ISBN 80-968011-3-9. (in Czech)

Patzek, T.W., 2006. The Real Biofuel Cycle. Berkeley: University of California, 48 p.

U.S. Environmental Protection Agency, 2002. A Comprehensive Analysis of Biodiesel Impacts on Exhaust Emission: Draft Technical Report [online]. Cincinnati, OH: National Service Center for Environmental Publications, October 2002, 118 p. Retrieved from: http://www.nbb.org/resources/reportsdatabase/reports/gen/20021001_gen-323.pdf

Wood, J.H., Long, R.G., Morehouse, F.D., 2004. Long-Term World Oil Supply Scenarios The Future is neither as Bleak or Rosy as some assert. Feature article. US Department of Energy, Energy Information Administration (USA). 